\title{
KEPEMIMPINAN YESUS KRISTUS MENURUT INJIL SINOPTIK \\ DAN RELEVANSINYA TERHADAP KEPEMIMPINAN ROHANI \\ MASA KINI
}

\author{
Yoseph Christian Thomassoyan \\ Jermia Djadi \\ sttjaffraymakassar@yahoo.co.id
}

\begin{abstract}
ABSTRAK
Adapun yang menjadi tujuan penulisan ini adalah sebagai berikut: Pertama, untuk memperoleh pengertian yang benar mengenai kepemimpinan rohani berdasarkan petunjuk Alkitab. Kedua, untuk menyelidiki dan mengungkapkan prinsip - prinsip kepemimpinan Yesus berdasarkan Injil Sinopsis dan bagaimana relevansinya bagi kepemimpinan rohani masa kini.

Metode yang penulis gunakan untuk mengumpulkan dan memperoleh data adalah studi kepustakaan (library research) yaitu penelitian terhadap buku - buku yang mendukung dan yang berkaitan dengan materi - materi yang dibahas dalam karya ini. Penelitian ini juga bersifat eksigesis yaitu menafsirkan suatu bagian Alkitab yang menjadi bahan penulisan karya ilmiah ini.

Seorang pemimpin rohani harus mencontoh dan meneladani kehidupan dan keteladanan Tuhan semasa hidup dan pelayanan-Nya. Setiap pengajaran-pengajaran yang diberikan kepada setiap orang yang mendengar, haruslah dapat merubah hidup orang yang mendengarkan berita keselamatan itu dan menjadikan mereka ciptaan baru seperti yang Tuhan Yesus ajarkan. Dalam bidang organisasi gereja, haruslah terdapat pembaruan, terutama dalam sikap dan perilaku seorang pemimpin kepada bawahan. Tuhan Yesus adalah Allah dan Tuhan, rela untuk melayani sebagai seorang hamba agar dapat menyelamatkan seluruh umat manusia.
\end{abstract}

Kata Kunci: Kepemimpinan Yesus, Injil Sinoptik, Relevansi dan Pemimpin Rohani Masa Kini.

\section{PENDAHULUAN}

\section{Latar Belakang Masalah}

Akhir-akhir ini pola pertumbuhan gereja sering dihubungkan dengan kemampuan seorang pemimpin dalam memimpin gereja tersebut. Seringkali menjadi pertanyaan, mengapa satu gereja bertumbuh dengan maju dan satu gereja yang lain tidak mengalami pertumbuhan baik secara kualitas 
maupun kuantitas? Sehingga patut untuk dipertanyakan kualitas yang dimiliki oleh pemimpin dalam gereja tersebut. Kepemimpinan menjadi sebuah hal yang perlu dan patut untuk dipelajari dan dikembangkan agar kepemimpinan dapat membawa manfaat yang besar dan berarti bagi orangorang yang dipimpinnya.

Yesus Kristus membawa perubahan yang sangat besar dalam kehidupan bangsa Israel terutama dalam pemahaman terhadap hukum taurat dan pola ibadah bangsa Israel. Tuhan Yesus adalah seorang pemimpin yang luar biasa, Dia mengkritik dan membawa sebuah perubahan dalam sikap dan pola hidup bangsa Yahudi yang dalam kehidupan mereka terlalu menekankan aturan-aturan hukum taurat, tetapi tidak melakukannya dalam hidup mereka secara benar. Kehidupan dan pelayan Tuhan Yesus sangat jelas digambarkan oleh penulis kitab Injil Matius, Markus dan Lukas yang dinamakan Injil Sinoptik, para penulis Injil Sinoptik adalah tangan pertama dan menjadi saksi mata dari kehidupan dan pelayanan Tuhan Yesus.

Seperti yang dikatakan oleh C. Peter Wagner yang dikutip oleh Pontas Pardede dalam sebuah buku berjudul Sebuah Bunga Rampai Pertumbuhan Gereja, bahwa faktor pendorong utama bagi pertumbuhan dalam suatu gereja lokal adalah gembalanya. Menurutnya, dalam setiap gereja yang dinamis dan bertumbuh, terdapat seorang yang merupakan kunci yang dipakai Tuhan sehingga terjadi pertumbuhan itu. ${ }^{2}$ Kepemimpinan rohani sering dikaitkan dengan kepemimpinan seorang gembala sidang dalam sebuah gereja lokal. Pendapat yang sama juga diutarakan oleh Paul Y. Cho yang dikutip oleh Pontas Pardede dalam buku Sebuah Bunga Rampai pertumbuhan Gereja, bahwa, "Pertumbuhan gereja tidak akan berlangsung menjadi kenyataan tanpa kepemimpinan yang aktif sang gembala." ${ }^{3}$

\section{Pokok Masalah}

Dengan melihat dan memahami permasalahan di atas maka penulis mengambil permasalahan pokok yaitu:

Pertama, apa dan bagaimana prinsip - prinsip kepemimpinan Yesus berdasarkan Injil Sinoptis.

Kedua, bagaimana relevansi kepemimpinan Yesus bagi pemimpin pemimpin rohani masa kini.

\footnotetext{
${ }^{1}$ Paul Enns, The Moody Handbook Of Theology ( Malang: Literatur SAAT, 2004), 96

${ }^{2}$ Pontas Pardede, Sebuah Bunga Rampai Pertumbuhan Gereja( Yogyakarta:Yayasan Andi,1994)31.

3 Idem
} 


\section{Tujuan Penulisan}

berikut:

Adapun yang menjadi tujuan penulisan penulisan ini adalah sebagai

Pertama, untuk memperoleh pengertian yang benar mengenai kepemimpinan rohani berdasarkan petunjuk Alkitab.

Kedua, untuk menyelidiki dan mengungkapkan prinsip - prinsip kepemimpinan Yesus berdasarkan Injil Sinopsis dan bagaimana relevansinya bagi kepemimpinan rohani masa kini.

\section{Manfaat Penulisan}

Harapan penulis kiranya melalui karya ilmiah itu dapat membawa manfaat bagi para pembaca khususnya bagi mereka yang terlibat dalam kepemimpinan rohani. Adapun manfaat yang diharapakan akan tercapai adalah sebagai berikut:

Pertama, dengan adanya penulisan karya ilmiah ini, diharapkann dapat menjadi bahan acuan bagi para pemimpin rohani, pendeta, gembala jemaat, guru Injil, kordinator komisi gereja dalam menjalankan tugas kepemimpinannya dan juga berguna bagi pada kaum awam yang ingin mengetahui lebih banyak mengenai prinsip - prinsip kepemimpinan yang alkitabiah.

Kedua, melalui penulisan karya ilmiah penulis banyak menemukan dan mengetahui pengetahuan yang baru mengenai kepemimpinan rohani sehingga menjadi bahan naskah yang berguna dalam menajalankan tugas kepemimpinan yang akan diemban nantinya.

Ketiga, untuk memenuhi salah satu persyaratan akademi dalam mencapai gelar Sarjana Teologia di Sekolah Tinggi Filsafat Teologia Jaffray Makassar.

\section{Metode Penulisan}

Metode yang penulis gunakan untuk mengumpulkan dan memperoleh data adalah studi kepustakaan (library research) yaitu penelitian terhadap buku - buku yang mendukung dan yang berkaitan dengan materi - materi yang dibahas dalam karya ini.

Penelitian ini juga bersifat eksigesis yaitu menafsirkan suatu bagian Alkitab yang menjadi bahan penulisan karya ilmiah ini.

\section{Batasan Penulisan}

Mengingat luasnya bidang cakupan studi kepemimpinan rohani yang ada dalam Alkitab, maka penulis memberikan batasan penulisan pada karya ilmiah ini hanya mengenai kepemimpinan Yesus berdasarkan Injil Sinopsis. 


\section{GAYA DAN POLA KEPEMIMPINAN YESUS KRISTUS \\ MENURUT INJIL SINOPTIK}

\section{Sekilas Mengenai Injil Sinoptik}

Untuk membahas dan memahami lebih jauh lagi mengenai pola-pola kepemimpinan Yesus Kristus dan teladan hidup-Nya menurut Injil Sinoptik, terlebih dahulu kita melihat pengertian dari Injil Sinoptik itu sendiri melalui beberapa pengertian dan defenisi dari sumber-sumber tertulis dan dari para ahli.

Pertama, pengertian kata "sinoptik" menurut Peter Salim dalam buku: The Contemporary English-Indonesia Dictionary, yaitu: "synopsis" (noun) "synopses" (plural) berarti ringkasan. Sinoptic memiliki arti (l) yang mengihktiarkan; (2) berkenaan dengan pandangan umum; (3) berpadangan yang kurang lebih sama atau paralel". ${ }^{4}$

Kedua, Pengertian "Injil Sinoptik" menurut Drewes, bahwa kata sifat sinoptik terbentuk dari istilah bahasa Yunani "synopsis" yang berarti "ikhtiar", istilah "synopsis" ini juga dapat diartikan sebagai "pemandangan secara bersama". Injil sinoptis dapat ditinjau secara bersama oleh karena kesamaan dan kesejajarannya yang besar.

Ketiga, Pengertian "Injil Sinoptik" menurut Xavier Leon Duffour dalam buku Ensiklopedia Perjanjian Baru, yaitu:

Sinoptik (Synoptic) dari bahasa Yunani "sinoptikos adalah kata sifat yang berkaitan dengan "syn-opsis" yang berarti "melihat bersama sama", dengan memungkinkan memandang sekali saja sambil melihat berbagai unsur yang

berbeda - beda. Dalam penjelasan Xavier tersebut, menunjukkan bahwa ketigakitab Injil yang pertama yaitu Injil Matius, Injil Markus dan Injil Lukas disebut sinoptik sebab berisikan banyak bagian yang sangat serupa dan berbeda sekaligus. ${ }^{6}$

Berdasarkan gambaran tentang pengertian Injil Sinoptik diatas, maka diambil suatu kesimpulan singkat bahwa pengertian Injil Sinoptik adalah tiga Injil yaitu Matius, Markus dan Lukas yang melihat secara bersamasama, memiliki banyak kesamaan dan sekaligus juga perbedaan. Adapun persamaan dari ketiga Injil ini menyoroti Yesus, antara lain: "Yesus memanggil kedua belas murid-Nya untuk menyertai Dia dan mengemban lanjutan misi - Nya bagi dunia ini" (Mat 10:1-4; 4:18-22; Mark 3:13-19; 1:6-20; Luk $6: 12-16$; 5:1-11). "Yesus mengajarkan tentang kerendahan hati" (Mat 18:1-5; Mark 9:33-37; Luk 9:46-48). Sedangkan perbedaan yang terdapat dalam ketiga Injil ini, antara lain: Pertama, Matius memandang Yesus Press, 1985)

${ }^{4}$ Peter Salim, The Contempary English - Indonesian Dictionary (Jakarta: Modern English

${ }^{5}$ B.F. Drewes, Satu Injil Tiga Pekabar (Jakarta: BPK Gunung Mulia, 1982), 22.

${ }^{6}$ Xavier Leon-Dofour, Ensiklopedia Perjanjian Baru (Yogyakarta: Kanisius, 1990), s.v. "synoptik" 
sebagai Raja/Mesias, Markus memandang Yesus sebagai hamba Allah yang menyerahkan diri-Nya sebagai korban keselamatan, Lukas memandang Yesus sebagai anak manusia itu sendiri. Kedua, secara khusus perbedaannya ialah: Markus menjelaskan secara detail bahwa kedatangan Yesus bukan untuk melayani, melainkan untuk melayani dan menebus dosa manusia (Mark 10:45), sedangkan Matius dan Lukas tidak. Injil Lukas lebih terperinci menjelaskan tentang perumpamaan-perumpamaan yang diajarkan oleh Yesus, sedangkan Injil Matius dan Markus tidak. Injil Sinoptik yaitu Injil Matius, Markus dan Lukas memandang bersama-sama kepada Yesus Kristus dan mendengar bersama-sama mengenai Tuhan Yesus baik secara langsung maupun secara tidak langsung, yang kemudian ditulis dalam bentuk tulisan yang dapat dimengerti dan dipahami.

Sehubungan dengan perspektif Injil Sinoptik tentang kepemimpinan Yesus, secara khusus diambil dari Injil Sinoptik yang ada hubungannya denngan kepemimpinan Tuhan Yesus dalam kehidupan dan pelayanan-Nya. Ketiga Injil ini menyajikan pola kepemimpinan dan kehidupan Tuhan Yesus yang sama, namun berbeda sudut pandang dan versinya.

Kepemimpinan Tuhan Yesus sangat jelas terlihat pada saat Ia mengadakan observasi untuk memilih dan memanggil kedua belas orang murid-Nya seperti yang terdapat dalam Matius 10:1-4; Markus 3:13-19; Lukas 6:19-12, Tuhan Yesus memanggil orang-orang yang dikehendaki-Nya dan mereka pun datang kepada-Nya, Ia menetapkan mereka, memberi mereka kuasa untuk mengusir roh-roh jahat dan untuk melenyapkan segala penyakit dan segala kelemahan. Dalam hal ini, Tuhan Yesus membimbing mereka, melatih dan menuntun hidup mereka agar mengikuti teladan kehidupan-Nya sehingga dapat mempersiapkan mereka untuk sasaran pelayanan-Nya. Dalam hal ini, Tuhan Yesus bertindak sebagai seorang pemimpin yang efektif.

\section{Gaya Kepemimpinan Yesus Kristus}

Berbicara mengenai gaya kepemimpinan, hal itu sangat erat hubungannya dengan oknum pemimpin yang menjalankan kepemimpinan itu sendiri. Dalam perjanjian baru, khususnya Injil Sinoptik tidak diuraikan secara mendetail bahkan tidak dijelaskan gaya-gaya kepemimpinan yang dipakai oleh Yesus selama pelayanan-Nya. Tetapi Yesus berbicara mengenai gaya kepemimpinan yang berhubungan dengan latar belakang kepemimpinan sekular non Yahudi yang otoriter yang dikontraskan dengan kepemimpinan agama Yahudi sendiri (Mat 20:25-26; Mat 23:8-11).

Dalam bagian ini, penulis memaparkan beberapa gaya/model kepemimpinan Yesus Kristus berdasarkan perspektif Injil Sinoptik.

\section{Mengajar}

Sewaktu Tuhan Yesus datang ke dunia, Ia memfokuskan kehidupan pelayanan-Nya untuk mengajar dan membimbing kedua belas murid-Nya agar mereka dapat meneruskan pelayanan yang dilakukan Tuhan Yesus. 
Dalam setiap kesempatan, dimanapun Tuhan Yesus melakukan pelayanan, Ia pasti melakukan pengajaran kepada orang banyak. J.M. Price dalam buku Yesus Guru Agung, mengatakan: "Mengajar adalah pekerjaan Yesus yang utama. Ia sering menyembuhkan seseorang, kadang-kadang melakukan mujizat, berkhotbah, tetapi yang terutama ialah mengajar. Ia menjadikan pengajaran sebagai alat utama untuk mengantar orang kepada penebusan dosa." Tuhan Yesus dalam Injil Yohanes 13:13 mengatakan bahwa "Kamu menyebut aku guru dan Tuhan, dan katamu itu tepat, sebab memang Akulah Guru dan Tuhan." Murid-murid mengakui bahwa Yesus adalah guru mereka yang memberikan pengajaran kepada mereka tentang hidup dalam kebenaran Allah. Yesus adalah Tuhan dan Guru, maka wajar jikalau dalam setiap pelayanan-Nya bersifat pengajaran.

Dalam mengajar, Yesus sangat memperhatikan metode mengajar yang leluasa dan efektif, sehingga Ia mengajar dengan kecakapan yang sempurna. ${ }^{8}$ Inilah teladan seorang pemimpin agung yang patut diteladani, karena Yesus menjadi satu dengan pengajaran yang dilakukan-Nya, sehingga hal adalah seorang guru yang efektif. Yesus adalah seorang guru yang efektif, dimana Ia mampu mengajar murid-murid-Nya melalui cara verbal dan non-verbal dalam tindakan hidup sehari-hari.

Dalam pengajaran-Nya, Tuhan Yesus mengubah pemahaman atau men-transformasikan pemikiran bangsa Yahudi dari lahiriah kepada sesuatu yang bersifat batiniah. Penekanan pengajaran Yesus dalam Matius 5:17-48 lebih menekankan kepada sikap hati manusia kepada Allah. Sementara pemimpin-pemimpin Yahudi melalui hukum Taurat lebih menekankan kepada sikap lahiriah kepada kepada Allah. Tuhan

\section{Melayani Sebagai Seorang Hamba}

Kata "Kehambaan" berasal dari akar kata "hamba" yang berarti "abdi, budak belian." Kata hamba menurut James Strong, adalah "bujang, pelayan dan abadi." 10

Yesus datang untuk melaksanakan misi-Nya menyelamatkan umat manusia dari dosa. Yesus datang dengan kerendahan hati-Nya untuk memberikan teladan yang harus dipanuti oleh murid-Nya dan semua manusia yang percaya kepada-Nya.

Pada masa pelayanan-Nya bersama-sama murid-Nya (pemerintah Romawi waktu itu), Yesus memberikan suatu perbandingan yang kontras dan mengajarkan murid-murid-Nya kepemimpinan yang bagaimana yang menjadi ciri mereka kelak jika mereka menjadi pemimpin. Mula-mula Yesus menunjuk kepada gaya kepemimpinan dunia zaman itu, yang hampir sama dengan zaman sekarang mengutamakan status, denominasi dan kekuasaan.

\footnotetext{
${ }^{7}$ J.M. Price, Yesus Guru Agung. (Bandung: LBB, 1975), 10

${ }^{8}$ Ibid, 17

${ }^{9}$ Kamus Besar Bahasa Indonesia. s.v. "hamba"

${ }^{10}$ James Strong, The Exhaustive Concordance Of The Bible. (Iowa: World Bible Publishers, n.d), s.v. "servant"
} 
Gottfried, mengatakan bahwa: "Gaya kepemimpinan demikian bulat-bulat ditolak oleh Yesus, dan ketimbang Ia gariskan dengan tegas bahwa kepemimpinan kristiani harus ditandai oleh pelayanan dengan rendah hati."ll

Yesus bereinkarnasi menjadi seorang hamba untuk melayani umat manusia, demi tujuan keselamatan kekal yang dianugerahkan oleh Allah Bapa melalui Dia. Gottried juga mengatakan bahwa: "sepanjang pelayananNya, khususnya dalam hubungan-Nya dengan murid-murid-Nya, Yesus konsisten mempraktekkan model kepemimpinan yang melayani ini, yang diharapkan-Nya akan menjadi jati diri pengikut-Nya." ${ }^{2}$ Firman Tuhan mengungkapkan bahwa: "sama seperti Anak Manusia datang bukan untuk dilayani, melainkan untuk melayani dan memberikan nyawa-Nya menjadi tebusan bagi banyak orang (Mat 20:28)". Melayani sebagai seorang hamba merupakan prinsip dasar yang diajarkan dan ditekan oleh Yesus dalam setiap pelayanan- Nya.

Yesus banyak memberikan prinsip kepemimpinan sebagai hamba kepada murid-murid-Nya. Yesus menghendaki agar suatu kelak di saat Yesus meninggalkan murid-murid-Nya sendirian, mereka dapat mempraktekkan dan mengajarkan orang lain melayani sebagai seorang hamba yang rendah hati sangat berkenan kepada Allah.

Kerendahan hati Yesus sebagai seorang hamba Allah untuk melaksanakan misiNya di bumi ini sangat nyata, sebagaimana yang rasul Paulus tuliskan kepada jemaat di Filipi, yang mengatakan: "Kristus Yesus, yang walaupun dalam rupa Allah,....mengosongkan diri-Nya sendiri, yang mengambil rupa seorang hamba" (Filipi 2:5-7). Dalam nats ini jelas bahwa Yesus menanggalkan kesetaraan dengan Allah sebagai milik yang harus dipertahankan (Fil 2:6), tetapi ia bersedia untuk melaksanakan dan menggenapi misi utama-Nya sebagai hamba yang setia dan taat kepada Bapa-Nya. Dengan demikian Yesus menjadi manusia sejati yang dapat mengalami, merasakan dan mengamati keadaan manusia sekelilingnya demi tujuan keselamatan-Nya.

Kepemimpinan Yesus sebagai hamba yang setia melayani terlihat juga pada waktu Yesus membasuh kaki murid-murid-Nya (Yoh 3:1-20). Kebenaran inilah yang hendak Yesus ajarkan kepada mereka, agar mereka tidak egoisme dan mementingkan diri sendiri, tetapi dapat saling melayani satu dengan yang lainnya. Yesus sebagai Tuhan dan Guru mereka telah melakukan hal itu, maka mereka pun wajib melakukannya. Kepemimpinan yang sejati menuntut kerendahan hati untuk melayani dan pengorbanan diri.

\footnotetext{
${ }^{11}$ Gottfried Osei-Mensah, Dicari Pemimpin Yang Menjadi Pelayan. (Jakarta: Yayasan Komunikasi Bina Kasih), 10

${ }^{12}$ Idem
} 


\section{Menjadi Teladan}

Menurut Kamus Besar Bahasa Indonesia, kata "keteladanan" dari akar kata , "teladan", yang berarti "patut ditiru, contoh", dan keteladan adalah hal-hal yang dapat ditiru/dicontoh. ${ }^{13}$

Dalam Alkitab, khususnya Injil Sinoptik tidak dijelaskan dengan terperinci mengenai keteladanan dari Tuhan Yesus dalam kepemimpinanNya, tetapi penulis mengambil dan menarik beberapa hal yang sangat berkaitan dengan prinsip keteladanan dari kehidupan dan pelayanan Yesus Kristus sendiri.

\section{Teladan dalam Berdoa}

Doa merupakan satu kata yang tidak pernah terlepas dari kehidupan dan pelayanan Tuhan Yesus. Dalam setiap langkah kehidupan dan pelayanan Tuhan Yesus, Dia senantiasa berdoa, di manapun dan kapan pun. Tuhan Yesus mempunyai kebiasaan mengundurkan diri ke tempat-tempat sunyi untuk berdoa (Lukas 5:11). Tuhan Yesus memberikan contoh dan teladan kepada murid-murid-Nya tentang bagaiman sikap doa yang baik dan juga seberapa penting-Nya doa itu dalam kehidupan dan pelayanan murid-murid saat menjadi pemimpin-pemimpin umat nantinya.

Doa mempunyai tempat yang sangat penting dalam kehidupan dan pelayanan Tuhan Yesus. J.L.Ch.Abineno mengatakan dalam bukunya yang berjudul Doa Menurut Kesaksian Perjanjian Baru bahwa panggilan dan tugas yang dipercayakan Allah kepada-Nya sebagai utusan-Nya, Ia terima dengan doa. Pekerjaan-Nya Ia lakukan dalam persekutuan dan percakapan dengan Dia. Lebih lanjut lagi Abineno mengatakan bahwa keputusan-keputusan penting yang berhubungan dengan panggilan-Nya, Ia baru ambil sesudah Ia berdoa dan menanyakan kehendak BapaNya dan akhirnya juga sengsaraNya untuk keselamatan manusia, Ia tanggung dalam persekutuan dengan Bapa-Nya, yang Ia hayati dalam doa-Nya. ${ }^{14}$

Tuhan Yesus adalah teladan yang agung dalam berdoa. Hal itu terlihat pada saat Ia memilih murid-murid-Nya untuk memulaikan proyek pelayanan-Nya yang besar, Firman Tuhan mengatakan: “.....Yesus pergi ke bukit untuk berdoa....Ia berdoa kepada Allah" (Luk 6:12). Sebelum Ia memanggil dan memilih murid-murid yang dipercayakan-Nya untuk tanggung jawab besar kelak, Ia terpilih dahulu bergumul kepada Allah memohon kehendak Bapa-Nya dalam pelayanan-Nya.

Tuhan Yesus berdoa saat menghadapi masa kritis dalam kehidupanNya di taman Gethsemany (Mat 26:26-46; Mark 14:32-42; Luk 22:29-46). Dalam pelayanan dan membina kehidupan murid-murid-Nya, Ia mengajarkan kepada mereka untuk selalu berdoa dan menyerahkan

\footnotetext{
${ }^{13}$ Kamus Besar Bahasa Indonesia. s.v. "teladan"

${ }^{14}$ J.L.Ch.Abineno, Doa Menurut Kesaksian Perjanjian Baru (Jakarta: BPK Gunung Mulia,1992), 4
} 
pergumulan hidup seutuhnya kepada Allah Bapa di Surga (Mat 6:9-13; 7:7ll; Luk 11:1-13).

\section{Teladan Dalam Kasih}

Allah adalah kasih (I Yoh 4:8,16). Tuhan Yesus adalah Allah yang menjelma menjadi manusia. Keteladanan kasih Allah bagi manusia terbukti sewaktu Ia mengutus Yesus Kristus untuk menyelamatkan umat manusia dari belenggu dosa (Yoh 3:16) Dalam kehidupan dan pelayanan-Nya sewaktu berada di bumi, Ia sangat mengutamankan kasih. Ia sangat mengasihi orang-orang berdosa (Mat 9:10; Luk 15:1,2). Kasih yang Tuhan Yesus miliki adalah kasih Agape, yaitu kasih yang memberi tanpa menuntut balasan, rela berkorban untuk mengutamakan kepentingan orang lain. Yesus Kristus sebagai pemimpin Agung dan sempurna banyak mengajarkan dan mempraktekkan kasih dalam pelayanan-Nya, bahkan dapat dikatakan bahwa kehidupan dan pelayanan Yesus Kristus adalah kasih.

Tuhan Yesus sangat mengasihi orang-orang yang dilayani-Nya. Tercatat dalam kitab-kitab Injil Sinoptik dimana Ia menyembuhkan orang sakit dan membangkitkan orang mati karena Ia sangat mengasihi mereka (Mat 9:18-26; mark 5:21-43; Luk 8:40-56).

Kasih menuntut pengorbanan sejati. J. Oswald Sanders mengatakan, "Ciri kepemimpinan yang sejati dapat ditemukan dalam orang-orang yang rela berkorban demi tujuan-tujuan yang sukup luhur, sehingga menuntut ketaatan sepenuh hati dari pihak mereka." 15 Tuhan Yesus sangat mengasihi manusia, terbukti saat Ia menyerahkan diri-Nya dikorbankan demi keselamatan manusia, untuk mendamaikan manusia berdosa dengan Allah (II Kor 5:8,21)

\section{Teladan dalam Pelayanan}

Dalam pelayanan-Nya, Tuhan Yesus banyak memberikan prinsipprinsip keteladanan yang harus dipanuti, dicontohi dan diteladani. Sebagai seorang pemimpin yang sempurna, Yesus telah mengobservasi dan mengevaluasi perencanaan pelayanan yang efektif. Tuhan Yesus mengatakan dalam Lukas 14:28, "Sebab siapakah di antara kamu yang kalau mau mendirikan sebuah menara tidak duduk dahulu membuat anggaran biayanya, kalau-kalau cukup uangnya untuk menyelesaikan pekerjaan itu." Seorang pemimpin yang baik, akan merencanakan anggaran terhadap biayabiaya yang diperlukan agar lebih mudah dalam mencapai tujuan yang telah ditetapkan.

Tuhan Yesus banyak melakukan pelayanan yang mempunyai arti yang sangat besar bagi hidup manusia. Ia melakukan banyak mujizat, menyembuhkan yang sakit, membangkitkan yang mati, mengusir setan, mengajarkan dan memberitakan kebenaran Firman Tuhan yaitu keselamatan di dalam Dia. Dalam perjalanan pelayanan-Nya, mukjiat merupakan salah satu pelayanan yang tidak bisa dilepaskan dari pribadi

\footnotetext{
${ }^{15}$ J. Oswald Sander, Kepemimpinan Rohani (Bandung: Kalam Hidup, 1979), 18
} 
Tuhan Yesus. Lima roti dan dua ekor ikan yang dapat mengenyangkan orang banyak menjadi salah satu mukjizat yang terkenal dalam Injil Sinoptik (Mat 14:15-21; Mark 6;35-44; Luk 9:12-17). Selain itu Tuhan Yesus juga menyembuhkan orang sakit (Mat 8:14-15\& 9:2-8; Mark 1:29-31 \& 2:212; Luk 4:38-39 \& 5:18-26) dan membangkitkan orang mati (Mat 9:18-19, 23-26) dan juga mengusir setan (Mat 8:28; Mark 5:1-20; Luk 8:26-39). Tuhan Yesus menunjukkan pelayanan yang seharusnya dilakukan oleh setiap pemimpin-pemimpin rohani yang ingin membawa perubahan dalam gereja. Seorang pemimpin rohani yang baik harus dapat menjadi seperti Yesus, mempunyai kuasa untuk melakuka mujizat-mujizat seperti perintah Tuhan dalam Mark 16:17-18.

Yang terakhir yang perlu kita perhatikan ialah bagaimana Tuhan Yesus melakukan pelayanan yang membawa orang untuk mendapat keselamatan di dalam Dia. Pelayanan yang dilakukan-Nya meliputi pelayanan secara umum dan pelayanan antar pribadi. Tuhan Yesus melakukan pelayanan secara massal yang dilakukan-Nya bersama dengan orang banyak. Ia melakukan banyak mujizat dalam pelayanan-Nya sehingga semakin banyak orang yang mengikuti Dia (Mat 14:13).

Tuhan Yesus dalam melaksanakan misi-Nya khususya untuk melanjutkan pelayanan-Nya kelak, Ia membutuhkan orang-orang yang dapat dipercayakan untuk tanggung jawab tersebut. Pertama-tama Tuhan Yesus berdoa untuk memilih murid-Nya (Luk 6;12), memilih sesuai dengan kebutuhan-Nya (Mat 10:1-4; Mark 3:3-19; Luk 6;12-16), kemudian Yesus mengajar dan membina murid-murid-Nya sesuai dengan pola hidup dan pelayanan-Nya dan setelah itu Tuhan Yesus mengutus mereka untuk terjun ke medan pelayanan (Mat 10:5; Mark 6:7), dan yang terakhir Yesus mengevaluasi hasil pelayanan murid-murid-Nya. Yesus adalah modeling pelayanan yang efektif.

\section{Pola Kepemimpinan Yesus Kristus}

Kepemimpinan yang berhasil dan efektif akan terlihat dari bagaimana caranya seorang pemimpin mengelola bahan-bahan dasar dan sumber daya yang ada. Menurut Kamus Besar Bahasa Indonesia, kata "pola" berarti "gambar yang dipakai untuk contoh; potongan kertas yang dipakai untuk contoh; sistem, cara kerja; bentuk (struktur) yang tetap."16 Kepemimpinan memerlukan sebuah sistem dan cara kerja yang baik agar kepemimpinan yang dijalankan dapat tersusun secara sistematis dan teratur sehingga dapat dengan dilaksanakan guna mencapai hasil dan tujuan yang maksimal.

Tuhan Yesus datang ke dunia ini memiliki tujuan yang spesifik terutama dalam pelayanan-Nya. Dia sebagai pemimpin yang Agung memiliki tujuan untuk menyelamatkan manusia dari dosa. Berdasarkan

\footnotetext{
${ }^{16}$ Kamus Besar Bahasa Indonesia s.v. "pola"
} 
tujuan itu, Tuhan Yesus merencanakan sebuah pola untuk mewujudkan apa yang Ia ingin lakukan bagi dunia ini, khususnya sewaktu Ia naik ke Sorga meninggalkan dunia ini. Tuhan Yesus ingin menunjukkan kepada kita bahwa seorang pemimpin yang baik dan handal adalah orang yang mempersiapkan tujuan yang jelas dan pola yang teratur dalam kepemimpinannya. Robert E. Coleman mengatakan: "Tujuan inilah yang menjadi dasar dari setiap kata dan perbuatannya, dan tujuan inilah mengatur langkahnya." ${ }^{17}$

Untuk lebih jelas mengetahui bagaimana pola kepemimpinan yang Yesus ajarkan dalam Injil Sinoptik, maka penulis memaparkan beberapa hal yang berhubungan erat dengan pola pengembangan kepemimpinan yang Yesus ajarkan dan terapkan dalam pelayanan-Nya bersama dengan muridNya.

\section{Pemilihan Murid}

Dalam Kamus Besar Bahasa Indonesia, kata "memilih" berarti "menentukan apa yang disukai, mencari atau memisah-misahkan mana yang baik, dan menunjuk (orang atau calon) dengan suaranya" ${ }^{18}$ Kata memilih menurut James Strong, berarti "memanggil, memerintahkan, mengumpulkan, mengundang, mempersilahkan, meminta, panggilan untuk, ke." ${ }^{19}$ Jadi memilih berarti menentukan, mencari, memisahkan, menunjuk dan memanggil mana yang baik.

Latar belakang Tuhan Yesus memilih dua belas murid-Nya adalah untuk memenuhi kebutuhan orang-orang yang dilayani oleh Yesus pada waktu itu. Tuhan Yesus melihat ladang Allah begitu luas, perlu pekerja yang banyak. Hal inilah yang mendorong atau memotivasi Yesus memilih murid-murid-Nya dan sekaligus untuk melanjutkan misi pelayanan-Nya setelah ia naik ke Surga. Kepribadian dan pelayanan para murid-murid Yesus sangat berpengaruh terhadap kehidupan gereja sampai masa kini.

Yesus memilih dua belas murid-murid-Nya (Matius 10:1-4; Markus 3:13-19; Lukas 6:12-16). Yesus adalah perencana Agung, sebelum Ia memilih murid-murid-Nya, yang kelak akan dipakai sebagai alat-Nya dan mempertanggung jawabkan kelanjutan pelayanan-Nya, Yesus terlebih dahulu berdoa kepada Bapa-Nya (Luk 6:12), agar kebutuhan pelayanan-Nya terpenuhi dengan orang-orang yang akan dipilih dan dipanggil-Nya.

Robert E Coleman mengatakan: "Tujuan utama dari rencana Tuhan Yesus ialah untuk memilih orang yang dapat memberikan kesaksian tentang hidup-Nya, dan melanjutkan pekerjaan-Nya sesudah Ia kemali kepada Bapa." ${ }^{20}$ Ketika Yesus memilih murid-murid-Nya yang dipersiapkan untuk dilatih, dibina dan terjun ke dalam pelayanan, Ia memilih orang-

\footnotetext{
${ }^{17}$ Robert E. Coleman, Rencana Agung Penginjilan (Bandung: Kalam Hidup, 1964), 11.

${ }^{18}$ Kamus Besar Bahasa Indonesia s.v. "Memilih"

${ }^{19}$ James Strong, The Exhaustive Concordance Of The Bible (Iowa: World Bible Publishers, n.d), s.v. "called".

${ }^{20}$ Robert E. Coleman, Rencana Agung Penginjilan (Bandung: Kalam Hidup, 1964), 13.
} 
orang yang berasal dari kalangan biasa. Menurut Robert E. Coleman, "Mereka adalah orang-orang yang mudah dipengaruhi dan mudah tersinggung. Singkatnya, mereka yang dipilih Allah menjadi pengikut-Nya adalah orang-orang dari berbagai tingkat dan golongan masyarakat pada waktu itu." ${ }^{21}$ Tetapi dibalik semua kekurangan yang terdapat dalam diri mereka masing-masing, dapat kita lihat sebuah kerinduan yang besar untuk mau hidup dalam ketaatan dan mau hidup dalam pengajaran dari Tuhan Yesus sendiri, seperti apa yang dikatakan Robert E. Coleman, yang mengatakan bahwa "Yang paling menonjol dalam diri mereka adalah kerinduan mereka terhadap Allah dan terhadap hal-hal yang nyata dalam kehidupan-Nya." 22

Tuhan Yesus adalah pemimpin selektif. Menurut Robert E. Coleman, "Orang-orang yang hendak dilatih harus dipilih dengan teliti dan dengan bijaksana, karena segala sesuatu yang dikerjakan melalui beberapa orang ini adalah untuk keselamatan orang banyak." 23 Tuhan Yesus tidak hanya selektif dalam memilih murid-murid-Nya, tetapi Ia juga menjelaskan dan memaparkan tantangan-tantangan yang dihadapi dan sebagai harga untuk mengikut Dia, seperti yang dikatakan-Nya kepada murid-murid-Nya, ".......Setiap orang yang mau mengikut Aku, ia harus menyangkal diri-Nya, memikul salibnya dan mengikut Aku" (Mat 10:38; Mark 8:34; Luk 14:27). Tuhan Yesus melatih mereka untuk mau mengikuti teladan hidup-Nya dalam setiap aspek kehidupan yang dijalani-Nya. Ia memimbing, melatih dan mempersiapkan mereka untuk melayani. Dalam hal ini, Yesus bertindak sebagai seorang pemimpin. Myron Rush mengatakan, "Pemimpin adalah seorang yang merekrut orang-orang untuk mengikuti teladan-Nya dan menuntun mereka sambil melatih mereka untuk melakukan hal yang dilakukan-Nya." 24

\section{Memperlengkapi Murid}

Kata "Mengembangkan" menurut Kamus Besar Bahasa Indonesia, adalah "menambah sesuatu supaya menjadi lengkap.".

Setelah Tuhan Yesus menyeleksi dan memilihi murid-murid-Nya yang akan mengikuti, menyertai dan melayani bersama-sama dengan Dia, kemudian Ia melengkapi mereka dengan kuasa - Nya. “......memberi kuasa kepada mereka untuk mengusir roh-roh jahat dan untuk melenyapkan segala penyakit dan kelemahan" (Mat 10:1; Mark 3:15). Sebelum muridmurid-Nya masuk dalam ladang pelayanan yang penuh dengan tantangan dan kuasa-kuasa kegelapan, Tuhan Yesus mengerti akan hal itu dan Ia pun melengkapi mereka dengan kuasa Ilahi. Kuasa berarti "Kemampuan atau kesanggupan (untuk berbuat sesuatu); kekuatan, wewenang atas sesuatu

\footnotetext{
${ }^{21}$ Ibid, 14.

${ }^{22}$ Ibid, 22.

${ }^{23}$ Idem

${ }^{24}$ Myron Rush, Pemimpin Baru (Jakarta: YPI "Imanuel”, 1991), 71.

${ }^{25}$ Kamus Besar Bahasa Indonesia s.v. "Lengkap”.
} 
atau untuk menentukan (memerintah, mewakili, mengurus,dsb) sesuatu; pengaruh (gengsi, kesaktian, dsb) yang ada pada seseorang karena jabatannya (martabatnya), mampu, sanggup." ${ }^{20}$ Dengan kuasa yang dimilikinya, seseorang mempunyai kemampuan untuk bertindak atau menentukan sesuatu hal dengan memperhatikan pengaruh-pengaruh yang ada padanya. Kuasa ini diberikan sebagai sesuatu pemandatan dalam menjalankan amanat.

Dalam Mat 10: dan Mark 3:15, kata kuasa dalam bahasa Yunani Exousia yang berarti "Kebesaran Penuh untuk bertindak, hak untuk bertindak yang tidak dapat dihalangi oleh siapa pun." ${ }^{27}$ Para murid diberikan kuasa (Exousia) untuk mengusir roh-roh jahat, melenyapkan segala penyakit dan segala kelemahan. Tanpa perlengkapan kuasa Ilahi ini, murid-murid akan mengalami kegagalan dalam menghadapi setiap tantangan dan hambatan yang ada dalam pelayanan. Kuasa Ilahi yang diberikan Tuhan dalam membantu para murid untuk lebih mengembangakan pelayanan mereka.

Sebelum Tuhan Yesus naik ke surga, Ia memerintahkan para murid Nya untuk menantikan janji Bapa di Yerusalem yaitu hari pencurahan Roh Kudus (Kis 1:4-5, 8). Dalam ayat ini, kata "Kuasa" diterjemahkan melalui kata Dynamis, yang berarti "Kekuatan, kemampuan, energy, kuasa dan otoritas. ${ }^{28}$ Dalam konsepsi Tuhan Yesus, orang yang melayani dan bekerja di ladang pelayanan-Nya, sangat membutuhkan Exousia dan Dynamis dari Allah yang empunyai pelayanan itu.

Selain Tuhan Yesus memperlengkapi murid-murid-Nya dengan kuasa Ilahi, Ia juga melatih dan mempersiapkan mereka untuk menjadi pemimpin yang tangguh dan penuh kuasa kelak. Seperti yang dikatakan oleh J. I. Packer dan kawan-kawan, "Tetapi Yesus membentuk kedua belas orang itu menjadi pemimpin-pemimpin yang tangguh dan saksi-saksi utama tentang iman Kristen. Kesuksesan mereka membuktikan kuasa untuk mengubah yang dimiliki oleh Yesus sebagai Tuhan." ${ }^{29}$ Ia banyak mengajar mereka melalui keteladanan hidup-Nya. Meskipun begitu, kadang para murid yang bersama-sama dengan Dia mengalami kegagalan untuk menjadi apa yang Tuhan Yesus inginkan (Mat 17:21; Luk 22:46) Tetapi hal itu tidak menurutkan hati Tuhan. Dia dengan penuh kasih mengajar dan menasehati mereka, dan yang paling penting mendoakan mereka (Yoh 17:126) sehingga para murid pun dapat menjadi apa yang Tuhan Yesus inginkan setelah Tuhan Yesus naik ke Surga dan dapat kita lihat hasil dari pelayanan mereka hingga saat ini.

\footnotetext{
${ }^{26}$ Kamus Besar Bahasa Indonesia s.v. "Kuasa".

${ }^{27}$ Herman Soekahar, Bagaimana Memotivasi Jemaat Melayani. (Malang: Gandum Mas, 1988), 26.

${ }^{28}$ Ibid, 27.

${ }^{29}$ J.I.Packer, Merril C. Tenney, William White Jr., Dunia Perjanjian Baru (Malang; Gandum Mas, 1933), 147
} 


\section{Mendelegasikan Tugas}

Kepemimpinan sangat berhubungan dengan bagaimana seorang pemimpin dapat mendelagasikan tugas dengan baik kepada bawahan-Nya. Kartini Kartono dalam bukunya yang berjudul Pemimpin dan Kepemimpinan mengatakan bahwa "Pemimpin harus mengenal dengan baik sifat-sifat pribadi pada pengikutnya, dan mampu menggerakkan semua potensi dan tenaga anak buahnya seoptimal mungkin dalam setiap gerak usahanya, demi suksesnya organisasi, juga bisa mengembangakan dan memajukan penganutnya menuju pada progres dan kesejahteraan." ${ }^{30}$ Dalam mendelegasikan sebuah tugas, seorang pemimpin sangat penting untuk memperhatikan bagaimana dan seberapa besar kemampuan bawahan-Nya yaitu potensi-potensi yang ada dalam diri mereka yang dapat digunakan untuk melaksanakan tugas yang diberikan

Kemampuan untuk mendelegasikan tugas merupakan suatu ketrampilan atau seni yang penting untuk dimiliki oleh setiap pemimpin. James Kouzes dan Barry Posner dalam buku mereka yang berjudul The Leadership Learning mengatakan bahwa "Setiap pemimpin, setiap orangharus berinisiatif untuk mengidentifikasi kontribusi-kontribusi individu, merayakan berbagai penyelesaian tugas, dan menciptakan atmosfer kepercayaan diri dan dukungan." 31 Seorang pemimpin yang baik harus mampu menciptakan sebuah suasana yang menyenangkan saat mendelegasikan sebuah tugas sehingga bawahan yang menerima tugas tersebut dapat menikmati tugas itu bukan sebagai beban melainkan sebagai acuan untuk menuju pada tingkat yang lebih baik lagi.

Kata Delegasi, menurut Kamus Besar Bahasa Indonesia, berarti "Penyerahan, pelimpahan wewenang." ${ }^{32}$ Sedangkan mendelegasikan berarti "melimpahkan wewenang"33 Jadi mendelegasikan adalah penyerahan, pelimpahan wewenang dan tanggung jawab dari seseorang yang memiliki wewenang kepada orang lain.

Charles J. Keating dalam bukunya yang berjudul Kepemimpinan: Teori dan Pengembangannya, mengatakan: “........delegasi adalah pemberian sebagain tanggung jawab dan kewibawaan kepada orang lain." ${ }^{34}$ Mendelegasikan sebuah tugas menuntut sikap yang baik dan kepercayaan yang tinggi dari seorang pemimpin untuk dapat mempercayakan sebuah tugas kepada bawahan-Nya. Dengan kepercayaan yang diberikan itu, maka bawahan

\footnotetext{
2008), 153. Baca, 2008), 41

James Kouzes dan Barry Posner, The Leadership Learning (Yogyakarta: Pustaka

${ }^{32}$ Kamus Besar Bahasa Indonesia, s.v. "Delegasi”

${ }^{33}$ Idem

${ }^{34}$ Charles J. Keating, Kepemimpinan: Teori dan Pengembangannya (Yogyakarta: Kanisius, 1988), 82
}

${ }^{30}$ Kartini Kartono, Pemimpin Dan Kepemimpinan (Jakarta: PT Raja Grafindo Persada, 
akan bertanggung jawab penuh untuk menjalankan tugas yang diberikan dengan efektif.

Tuhan Yesus sewaktu menyelesaikan pekerjaan-Nya dan pelayananNya di dunia ini, kemudian kembali kepada Bapa-Nya di Surga mendelegasikan tugas yang sangat perlu untuk dilanjutkan oleh para murid demi keselamatan seluruh dunia. Tuhan Yesus mendelegasikan sebuah tugas yang amat agung tetapi juga amat berat untnuk dilaksanakan yaitu memberitakan Injil ke seluruh dunia, memuridkan dan membina setiap orang untuk mengenal dan semakin dewasa di dalam Dia (Kol l:28; Ef 4:13) dan amanat Agung tersebut dapat kita lihat dalam Injil Matius 28:18-20; Markus 16:15-18.

Tuhan Yesus mendelegasikan amanat Agung kepada murid-muridNya untuk pergi, "karena itu pergilah, jadikanlah... baptislah.... ajarlah." (Mat 28:19-20) Yesus menyuruh murid-murid-Nya untuk menjadikan semua bangsa murid-Nya Ia memberikan kewajiban bagi para murid untuk membaptis orang-orang yang percaya dan mengajar mereka. Murid-murid bertindak sebagai pelaksana amanat Agung sesuai dengan kehendak Yesus. Tuhan Yesus telah memulai sebuah tugas dan pelayanan dan Ia ingin agar tugas-Nya diteruskan oleh para murid-Nya. Myron Rush mengatakan: "Karena itu amanat Agung merupakan sebuah amanat untuk meneruskan tugas yang telah dimulai oleh Tuhan Yesus Kristus." 35 Agar amanat ini dapat terlaksana, maka diperlukan adanya orang-orang yang bertindak untuk memulai tanggung jawab tersebut.

\section{Mengevaluasikan Tugas}

Dalam sebuah kepemimpinan, evaluasi merupakan tindakan terakhir yang dilakukan dari keseluruhan tindakan dan pelaksanaan pola kepemimpinan yang ada. Dengan adanya evaluasi, maka seorang pemimpin dapat mengetahui keberhasilan dan kegagalan yang terjadi dan hal-hal apa saja yang perlu diperhatikan dalam upaya untuk mengembangkan kepemimpinan tersebut.

Kata "Evaluasi" menurut Kamus Besar Bahasa Indonesia berarti "penilaian, sedangkan mengevaluasi berarti "menilai, memberi penilaian."36 Terhadap sesuatu kewajiban yang telah ditentukan untuk dilakukan.

Yesus setelah melatih, mempersiapkan para murid-Nya untuk terjun ke pelayaan, dilengkapi dengan kuasa, diutus dan kemudian mereka kembali kepada Yesus dan Tuhan Yesus mengevaluasi pekerjaan dan pelayanan yang mereka lakukan. Tuhan Yesus memberikan waktu khusus untuk mendengarkan dan mengevaluasi pekerjaan mereka. Markus 6:30-32 dan Luk 9:10-1 mengatakan "Kemudian rasul-rasul itu kembali berkumpul dengan Yesus dan membertahukan kepada-Nya semua yang mereka kerjakan dan ajarkan....marilah ke tempat yang sunyi, supaya kita sendirian

\footnotetext{
${ }^{35}$ Myron Rush, Pemimpin Baru, (Jakarta: YPI “Immanuel”, 1991), 72.

${ }^{36}$ Kamus Besar Bahasa Indonesia s.v. "Evaluasi”
} 
dan beristirahat seketika...." Tuhan Yesus mengadakan evaluasi kerja bersama dengan para murid untuk mengetahui sejauh mana pelaksanaan tugas yang diberikan kepada mereka. Menurut Robert E. Coleman, "Ini merupakan strategi Yesus dalam seluruh pelayanan-Nya. Apabila Ia meninjau kembali pengalaman merek, Ia menunjukkan cara yang praktis untuk diterapkan dalam kehidupan." ${ }^{37}$

Yesus mengevaluasi tugas para murid yang diutus-Nya pertama dan kedua dengan selektif dan efektif, dimana para murid melaporkan segala hasil kerja Allah melalui mereka (Mark 6"30; Luk 9:10; 10:17-20). Akhir dari semuanya, Tuhan Yesus berkata: "Namun demikian janganlah bersukacita karena roh-roh takluk kepada-Nya, tetapi bersukacitalah karena namamu terdaftar di Surga" (Luk 10:20)

\section{RELEVANSI KEPEMIMPINAN KRISTUS YANG MEMBAWA TRANSFORMASI TERHADAP KEPEMIMPINAN ROHANI MASA KINI}

Kepemimpinan Rohani masa kini membutuhkan sebuah pembaharuan atau transformasi yang menyeluruh dalam berbagai aspek kepemimpinan yang dapat membawa keberhasilan dalam bidang organisasi terutama dalam gereja sebagai tubuh Kristus. Selain itu, perlu juga pemimpin-pemimpin dalam Gereja Tuhan yang dapat memimpin dan mengembangkan suatu sistem atau pola yang efesien dalam menjalankan tanggung jawab sesuai dengan rencana, kehendak dan teladan Yesus Kristus, yang adalah seorang pemimpin Agung dan Kepala Jemaat (gereja) itu.

Dalam bab ini, penulis merelevansikan kepemimpinan Yesus dalam empat bagian penting dimana melalui bagian-bagian ini, seorang pemimpin dapat belajar dan tahu bagaimana menjalankan sebuah kepemimpinan ala Yesus dan dapat membawa pembaruan yang berarti bagi organisasi gereja.

\section{Melalui Organisasi Gereja}

Jhon Stot mengatakan: "Segala tanggung jawab yang dipercayakan Allah kepada gereja-Nya telah dipercayakan-Nya kepada seluruh gerejaNya." ${ }^{38}$ Sondang P. Siagian seperti yang dikutip oleh Kartini Kartono dalam bukunya yang berjudul Pemimpin dan Kepemimpinan mengatakan, "Organisasi adalah setiap bentuk persekutuan antara dua orang atau lebih yang bekerja sama untuk mencapai tujuan bersama, dan terikat secara formal dalam satu ikatan hierarki di mana selalu terdapat hubungan antara seorang atau

\footnotetext{
${ }^{37}$ Robert. E. Coleman Rencana Agung Penginjilan (Bandung: Kalam Hidup, 1964), 70

${ }^{38}$ John Stott, Satu Umat (Malang: Seminary Alkitab Asia Tenggara, 1990), 20.
} 
sekelompok orang yang disebut pimpinan dan seorang atau sekelompok orang yang disebut bawahan." ${ }^{39}$ Gereja menjadi sebuah organasasi yang dijalankan dengan Yesus Kristus sebagai kepada (Ef 1:22), dan jemaat Tuhan sebagai Tubuh Kristus. Tuhan Yesus memerintahkn agar ada persekutuan yang indah dalam tubuh-Nya sehingga persekutuan ini dapat menyenangkan hati-Nya.

Dalam organisasi gereja, ada orang-orang yang diperlengkapi dengan karunia-karunia mempimpin, mereka itulah yang diutus oleh Allah untuk mengatur, mengayomi dan mendirikan gereja atau jemaat. Mat 16:18, Tuhan Yesus berkata kepada Petrus untuk membangun tubuh-Nya yaitu gereja Tuhan. Ada pemimpin-pemimpin dalam tubuh Kristus atau gereja Tuhan yang membangun gereja atau jemaat Tuhan dari tidak ada menjadi sebuah persekutuan yang indah. Para pemimpin yang terdapat dalam organisasi gereja tersebut adalah sarana utama yang digunakan Allah untuk menjaga umat-Nya agar tetap bergerak ke arah yang benar dan mengerjakan hal yang benar.

Tuhan Yesus mengadakan transformasi yang besar dalam struktur kepemimpinan Rohani yang terdapat dalam agama saat itu. Dalam ketiga Injil Sinoptik yaitu Matius 23:1- 6; Mark 12:38-40; Luk 11:37-54, Tuhan Yesus mengajarkan tentang perbedaan yang terdapat dalam kepemimpinan organisasi yang dijalankan oleh pemimpin-pemimpin agama Yahudi dengan apa yang dia terapkan dalam kepemimpinan-Nya. Kebiasaan-kebiasaan yang dilakukan pemimpin-pemimpin rohani pada saat itu, dianggap Tuhan Yesus sebagai suatu hal yang bersifat munafik, gila hormat, mementingkan kepentingan lahiriah dan tidak dapat melihat kebutuhan umat (Matius 23:2-7).

Namun di atas semua itu, Tuhan Yesus memberikan teladan kepemimpinan yang sebenarnya harus dilakukan pemimpin-pemimpin rohani dalam organisasi gereja yang dipimpin-Nya, yaitu bahwa mereka harus merendahkan diri terhadap orang-orang yang dipimpin-Nya (Mat 23: 8). Hierarki kepemimpinan memang harus tetap dijalankan, tetapi seorang pemimpin yang baik dan penuh Roh Kudus adalah seorang pemimpin yang tahu menempatkan dirinya dalam kedudukan sebagai seorang pemimpin organisasi serta seorang saudara dalam tubuh Kristus. Selain itu, seorang pemimpin yang baik harus dapat melayani orang lain (Mat 23:11). Memimpin ala Tuhan Yesus, bukanlah memimpin dengan menggunakan kekuasaan atau bergaya otoriter, melainkan memimpin dengan penuh kasih dan mau berkorban bagi orang lain. Baik itu orang lain yang dipimpinnya maupun orang lain yang berada di sekitarnya.

Ken Blanchard dan Phil Hodges dalam buku mereka yang berjudul Lead Like Jesus mengatakan, "Selama masa hidup-Nya di bumi, Tuhan Yesus

\footnotetext{
2008), 7-8.

${ }^{39}$ Kartini Kartono, Pemimpin Dan Kepemimpinan (Jakarta: PT Raja Grafindo Persada,
} 
membangun satu model cinta yang berkorban untuk memastikan bahwa para pengikut-Nya dipersiapkan untuk melanjutkan gerakan itu." ${ }^{40}$ Tuhan Yesus memberikan teladan yang baik dan Ia ingin agar setiap orang yang menjadi pemimpin dalam gereja atau tubuh Kristus, memimpin dengan penuh kasih dan cinta untuk melayani, rela berkorban dan tidak menggunakan hierarki kepemimpinan organisasi untuk mencapai kepentingan sendiri, melainkan untuk mencapai tujuan dan kepentingan Allah sendiri.

\section{Melalui Paradigma atau Pemahaman Pikiran}

Dalam bukunya yang berjudul Re-Code Your Change DNA, Renald Kasali mengutarakan pengertiannya tentang pikiran, yaitu: "suatu sistem yang memikirkan dan memutar gerak roda organisasi agar ia terus hidup. Pikiran bekerja dari suatu proses yang saling terkait satu dengan yang lainnya." ${ }^{41}$ Untuk memulai mengubah sebuah organisasi menjadi lebih baik lagi, maka sangat diperlukan perubahan pemahaman yang telah ada yang selama organisasi itu berjalan justru menjadi penghambat sehingga organisasi tersebut tidak maju.

Yang menarik dari kepemimpinan yang Tuhan Yesus lakukan sewaktu Ia hidup dan melayani di dunia ini adalah Tuhan Yesus mengubah pemahaman dan paradigma yang ada yang ditanamkan oleh pemimpin agama Yahudi saat itu dan menggantikan dengan paradigma yang baru yang bersumber dari Allah sendiri.

Tuhan Yesus mengajarkan bagaimana menjadi seorang pemimpin tranformator yang dapat mengubah paradigma dan pemahaman yang telah ada kepada pola pikiran dan pemahaman Kristus sendiri. Yesus Kristus dalam pengajaran-Nya berusaha memberikan pemahaman yang benar mengenai Kerajaan Allah dan bagaimana untuk dapat memperoleh keselamatan. Ken Blanchard dan Phil Hodges mengatakan, "Melalui seluruh pelayanan-Nya, Yesus berbicara tentang kerajaan Allah-nilainya, pengajarannya, perumpamaan, mukjizat, dan kepenuhan akhirnya, Dia memberi para murid-Nya suatu gambaran yang jelas tentang masa depan dan mereka bertekad untuk memenuhi masa depan itu." ${ }^{42}$ Visi yang dimiliki Tuhan Yesus, Ia utarakan dalam setiap pengajaran - Nya melalui beberapa perumpamaan tentang Kerajaan Allah (Mat 13:1-53; Mark 4:1-34; Luk 8:418) dan akhirnya perlahan-lahan mengubah paradigma dan pemahaman pikiran para murid dan orang-orang yang mendengar pengajaran-Nya serta melihat teladan hidup-Nya.

Tranformasi dalam paradigma dan pemahaman pikiran lebih jauh lagi Tuhan Yesus terapkan dalam setiap pengajaran-Nya. Matius 5:17-48, Tuhan

\footnotetext{
${ }^{40}$ Ken Blanchard dan Phil Hodges, Lead Like Jesus (Jakarta: Visimedia, 2006) , 58.

${ }^{41}$ Renald Kasali, Re-Code Your Change DNA, (Jakarta: PT Gramedia Pustaka Utama, 2007), 157.

${ }^{42}$ Ken Blanchard dan Phil Hodges, Lead Like Jesus (Jakarta: Visimedia, 2006) ,118.
} 
Yesus mengubah pemahaman umat Allah, yaitu bangsa Israel secara umum, sebelumnya mereka memahami ketaatan kepada Allah dengan berusaha untuk menjalankan perintah agama dengan sungguh-sungguh melalui hukum taurat. Tetapi Tuhan Yesus mengajarkan hal yang lain, Ia tidak mengubah hukum taurat, tetapi menggenapinya dan menjadikan-Nya murni seperti yang Ia inginkan. Dalam pasal ini, Tuhan Yesus lebih menekankan pengajaran-Nya kepada pembaharuan hati manusia. Sebelumya, umat Allah tidak memperhatikan masalah batiniah mereka. Standar moral yang Tuhan Yesus ajarkan sangat tinggi dan lebih sempurna daripada yang tertulis dalam hukum taurat, seperti yang dikatakan-Nya dalam Matius 5:17, "....... Aku datang bukan untuk meniadakannya, melainkan untuk menggenapinya." Tuhan Yesus menetapkan suatu ajaran dan pola beribadah yang baru dalam kehidupan umat Allah baik bagi bangsa Israel juga bagi seluruh umat manusia yang percaya kepada-Nya.

Tuhan Yesus dalam kepemimpinan-Nya mengadakan inovasi keagamaan dalam strukrur agama Yahudi. John H. Zenger dan Joseph Folkman dalam buku mereka yang berjudul The Handbook for Leaders mengatakan, "Inovasi berkaitan dengan kemampuan seorang pemimpin untuk memiliki pandangan yang segar dalam mendekati masalah, meninggalkan cara lama dan melihat kemungkinan-kemungkinan yang baru." ${ }^{33}$ Tuhan Yesus mengadakan inovasi-inovasi dalam setiap pengajaran yang Ia ajarkan sehingga membawa umat Tuhan yang mendengar, terbuka wawasannya dan mulai mengalami pembaruan dalam hidup mereka.

Pembaharuan pikiran dalam jemaat Tuhan akan diawali oleh sebuah pemahaman pikiran dari seorang pemimpin. Tuhan Yesus menaruh visi dan misi kepada para murid dan mengajarkan kepada orang-orang yang ikut dalam setiap pengajaran-Nya. Untuk dapat mengubah pemahaman dan paradigma yang telah ada, maka pikiran seorang pemimpin rohani harus sama dengan Kristus. Gottfried Osei-Mensah mengatakan dalam bukunya yang berjudul Dicari Pemimpin Yang Menjadi Pelayan mengatakan, "Jemaat Tuhan hanya layak dipimpin seorang pelayan yang senantiasa dibarui akal budinya oleh hikmat dan Roh Allah." ${ }^{44}$ Menjadi seorang pemimpin rohani yang membawa transformasi seperti yang Tuhan Yesus lakukan, terlebih dahulu harus menyerahkan seluruh hidupnya untuk dikuasai oleh Tuhan lewat Roh Kudus agar setiap pemikiran dan pemahaman yang dihasilkan dapat mengubah pemahaman dan paradigma umat Tuhan dan orang-orang yang dipimpinnya menjadi lebih sempurna sama seperti Kristus yang adalah sempurna (Mat 5:48).

\footnotetext{
${ }^{43}$ John H. Zenger dan Joseph Folkman, The Handbook for Leaders, (Jakarta: PT Bhuana Ilmu Populer, 2004), 21-22.

${ }^{44}$ Gottfried Osei-Mensah, Dicari Pemimpin Yang Menjadi Pelayan, (Jakarta: Yayasan Komunikasi Bina Kasih/OMF), 44.
} 


\section{Melalui Sikap dan Tingkah Laku}

Menjadi seorang pemimpin yang baik tidak hanya bagaimana memberikan teori-teori yang dapat mengubah sikap seseorang, tetapi juga kita harus menunjukkan contoh yang nyata melalui sikap dan tingkah laku kita sebagai teladan hidup bagi semua orang yang kita pimpin secara umum bagi jemaat Tuhan.

Tuhan Yesus mengajarkan beberapa contoh dan teladan dalam hidup dan pelayanan-Nya sebagai seorang pemimpin yang baik yaitu dalam doa, otoritas kepemimpinan-Nya, tutur kata dan sikap hidup-Nya di tengah umat Tuhan. Markus 1:35-39, Tuhan Yesus menunjukkan sikap yang baik dalam berdoa. Dia pergi ke tempat yang sunyi dan berdoa di pagi hari. Seorang pemimpin rohani yang mau men-transformasi organisasi gerejanya menjadi lebih baik lagi, harus memperhatikan kehidupan doanya. Mengawali setiap rencana dan tindakannya terhadap organisasi gereja yang dipimpinnya dengan berdoa kepada Tuhan sang empunya gereja.

Selain itu, Tuhan Yesus juga menunjukkan otoritas kuasa yang dimiliki-Nya. Ia tidak menerima perintah siapapun. Dalam Matius 16:1-4, Tuhan Yesus menegur pemimpin-pemimpin agama Yahudi yang mencobai Dia dengan meminta mujizat. Tuhan Yesus melakukan semua pelayananNya berdasarkan kehendak dari Bapa (Mat 3:15). Tuhan Yesus tunduk dan mau menuruti apa yang Tuhan Allah perintahkan untuk Dia lakukan. Meskipun kadang apa yang Dia lakukan bisa saja menurunkan martabatNya sebagai seorang yang penuh kuasa dari tempat yang maha tinggi. Namun Dia tetap tunduk kepada otoritas yang berada di atas-Nya yaitu Allah Bapa. Sebagai seorang pemimpin transformator, kita harus tunduk kepada otoritas yang berada di atas kita yaitu Tuhan Yesus yang telah memberikan pelayanan ini untuk kita.

Tuhan Yesus juga menunjukkan sikap yang baik melalui tutur kata yang bijaksana dan bagaimana cara menjawab sebuah pertanyaan tanpa mengorbankan kepentingan-kepentingan yang ada termasuk kepentingan kita. Seorang pemimpin terkadang tidak bisa mempengaruhi orang lain karena perkataan dan tutur kata yang jelek dan tidak sopan sehingga membuat orang lain atau bawahannya menjadi tersinggung. Dalam Matius 22:15-22; Mark 12:13-17 dan Luk 20:20-26, Tuhan Yesus menjawab pertanyaan yang hendak mencobai Dia yang datang dari pemimpinpemimpin agama Yahudi. Meskipun Tuhan Yesus tahu bahwa maksud mereka adalah jahat, tetapi dengan kasih-Nya yang besar bagi umat manusia, Ia tidak menjawab mereka dengan kasar tetapi dengan jawaban yang bijaksana yang tidak merugikan diri-Nya dan tidak menyinggung kaisar Roma dimana hal itu akan membahayakan hidup-Nya. Sebagai seorang pemimpin rohani yang mau membawa transformasi bagi organisasi gereja-Nya, maka kita harus dapat mengambil sikap dan tutur kata yang bijaksana, memperbaharui hati kita sehingga kita mengeluarkan 
perbendaharaan yang baik (Mat 12:35) yang dapat membangun jemaat Tuhan dan dapat mengubah hidup orang yang dipimpinnya.

Dan yang terakhir, Dia menunjukkan sikap seorang pemimpin yang membawa perubahan melalui sikap hidup-Nya. Robert D. Dale dalam bukunya yang berjudul Pelayanan sebagai Pemimpin mengatakan, "Yesus dalam Injil Sinoptik menyebut orang percaya sebagai murid-murid atau pelajarpelajar. Diciptakan kembali oleh Kristus yang memanggil kita untuk meninggalkan dosa, memikul salib, memutuskan ikatan-ikatan keluarga, menghadapi sorotan dan rajaman orang-orang yang fanatik mempertahankan tradisi, berkawan dengan orang-orang terbuang dan penipu-penipu dan orang-orang mati, dan meninggal dalam kehinaan, suatu kegagalan total bila diukur dengan skala keberhasilan "manusia organisasi". Kehidupan semacam ini adalah kehidupan yang mungkin paling radikal." Tuhan Yesus mengajarkan sikap hidup yang benar-benar berpusat kepada Tuhan saat melakukan pelayanan. Dengan tidak memandang suku, ras dan tabiat manusia, Tuhan Yesus bergaul dan memancarkan cahaya surgawi ke dalam kehidupan mereka sehingga mereka mengalami pembaruan budi. Sikap hidup dan tingkah laku yang mencerminkan seorang pemimpin yang radikal dalam segala aspek hidupnya kepada Allah. Sebagai pemimpin rohani masa kini, sikap hidup seperti Tuhan Yesus sangat diperlukan untuk menjadi sebuah dasar dan acuan untuk mempimpin dan mengubah hidup orang lain menuju ke arah yang lebih baik.

\section{Melalui Pelayanan}

Sikap kepemimpinan Tuhan Yesus yang maju melayani orang lain dengan hati hanmba mencerminkan kepemimpinan yang menghasilkan pengaruh yang kuat. Tuhan Yesus melakukan pelayanan dengan banyak mengadakan mujizat-mujizat, melalui pengajaran-pengajaran dan melalui teladan hidupnya yang sangat berbeda dengan pemimpin agama pada saat itu.

Alan E. Nelson mengatakan dalam bukunya yang berjudul Spirituality \& Leadership, "Jika Yesus adalah tokoh panutan paling tepat dalam hal kepemimpinan rohani, kita dapat belajar banyak dari ayat-ayat yang menggambarkan sikap Yesus dimana setelah Ia mengajar murid-murid-Nya untuk menjadi yang terkecil jika mereka ingin menjadi yang besar, Yesus mempraktekkan apa yang dikhotbahkan-Nya." Lebih jauh lagi dia mengatakan, "Hasil dari sikap-Nya yang merendahkan diri-bahkan mati di kayu salib-Allah memuliakan Dia ke tempat yang paling tinggi. Yesus secara konsisten mempraktekkan apa yang disebut melepaskan hak-hak-Nya." 46 Dalam pelayanan-Nya, Tuhan Yesus tidak hanya sampai mengajar orangorang yang mengikuti Dia, tetapi Ia mempraktekkan apa yang disampaikan-

\footnotetext{
${ }^{45}$ Robert D. Dale, Pelayanan sebagai Pemimpin (Malang: Gandum Mas, 1997), 53

${ }^{46}$ Alan E. Nelson, Spirituality and Leadership (Bandung: Kalam Hidup, 2007), 82
} 
Nya dalam kehidupan-Nya sehari-hari. Pelayanan-Nya semakin berkembang pesat karena didasari atas sikap kerendahan hati yang luar biasa besar. Agar kepemimpinan dapat berkembang maju dan pesat maka seorang pemimpin rohani haruslah bersikap rendah hati dan mempraktekkan apa yang telah dikatakan.

Tuhan Yesus melakukan banyak pelayanan mujizat dan kesembuhan. Dalam Injil Sinotiptik yang telah dibahas dalam bab sebelumnya, Tuhan Yesus melakukan pelayanan-Nya dengan menggunakan kuasa Ilahi yang ada pada-Nya. Seorang pemimpin rohani yang mau berhasil dalam pelayanNya, haruslah mampu menggunakan kuasa ilahi yang dari Roh Kudus, agar mampu mengadakan mujizat dan kesembuhan sehingga pelayanannya akan berhasil. Tuhan Yesus berjanji dalam Yoh 14:12, bahwa kita sebagai orangorang yang percaya kepada-Nya, yang beroleh janji-janji-Nya akan menerima pelayanan yang lebih besar lagi dari apa yang telah Ia lakukan. Dengan begitu maka seorang pemimpin rohani memerlukan kuasa yang besar untuk mewujudkan kerinduan hati Tuhan Yesus.

Ken Blanchard dan Phil Hodges mengatakan, "Salah satu pelayanan terbesar yang seorang pemimpin berikan kepada para pengikutnya adalah kepastian tujuan." 47 Tuhan Yesus memberikan kepastian kepada para pengikut-Nya bahwa dengan melalui Dia maka akan beroleh tujuan akhir hidup ini yaitu keselamatan kekal (Yoh 14:6). Tuhan Yesus sangat sadar tentang apa yang menjadi kebutuhan dari pengikut-pengikut-Nya sehingga Ia pun dengan penuh kasih, ketekunan dan kesabaran rela untuk mengajar, membimbing, menasehati, mendoakan bahkan rela mati untuk menebus dosa seluruh pengikut-Nya dan umat manusia secara umum yang mau jadi pengikut-Nya. Kepemimpinan yang berhasil dan dapat membawa pembaruan yang lebih baik lagi adalah kepemimpinan yang dapat melakukan pelayanan yang terbaik kepada orang-orang yang dipimpin-Nya menuju kepada tujuan Allah sendiri.

James Kouzes dan Barry Posner dalam buku yang mereka tulis yang berjudul A Leaders Legacy mengatakan, "Ketika kita hidup, orang tidak mengingat kita lantaran apa yang telah kita lakukan untuk diri kita sendiri. Mereka mengenang kita untuk apa yang kita perbuat bagi mereka. Merekalah pewaris karya-karya kita." Lebih lanjut lagi mereka mengatakan, "Salah satu yang menjadi kebahagiaan terbesar dan tanggung jawab dasar para pemimpin adalah memastikan bahwa orang-orang yang mereka perhatikan selama ini menjalani hidup tidak hanya sekedar sukses melainkan juga bermakna." 48 Seorang pemimpin yang baik akan dikenang seumur hidupnya bahkan sampai dia mati pun akan tetap dikenang sebagai sebuah sejarah. Tuhan Yesus sangat terkenal hingga saat sekarang ini

\footnotetext{
${ }^{47}$ Ken Blanchard dan Phil Hodges, Lead Like Jesus (Jakarta: Visimedia, 2006) , 141.

48 James Kouzes dan Barry Posner, A Leaders Legacy, (Jakarta: PT Bhuana Ilmu Populer, 2007), 2
} 
karena semua pelayanan dan pekerjaan yang dikerjakan-Nya sewaktu dia hidup dan melayani dalam dunia ini, dapat menjamah dan mengubah hidup pengikut-pengikut-Nya serta bawahan-Nya sehingga setiap ajaran yang disampaikan oleh para murid mendapat tanggapan yang baik dan respon positif sehingga dapat diterima dengan baik oleh umat manusia dan menghasilkan proses perubahan yang baik.

\section{PENUTUP}

\section{Kesimpulan}

Dari uraian bab-bab terdahulu bahwa kepemimpinan itu erat hubungannya dengan oknum yang memimpin. Untuk mengubah atau mentransformasikan organisasi gereja kepada perubahan yang lebih baik, maka diperlukan kepemimpinan yang mau diubah dan ditransformasikan. Sebuah perubahan menyangkut tentang segala aspek yang ada dalam kepemimpinan dan organisasi terutama saat terjadi pergantian kepemimpinan. Dengan sikap yang baik dan pemahaman yang benar mengenai tugas dan tanggung jawab yang diemban, maka kepemimpinan itu akan berjalan dengan efektif dan akan membawa pembaruan yang besar bagi organisasi yang dijalankan.

Yesus Kristus adalah pemimpin Agung yang sempurna, dalam sikap, perilaku, perkataan dan dalam segala aspek kehidupan yang ada. Dalam injil sinoptik dipaparkan dengan jelas dan teliti bagaimana gaya kepemimpinanNya yang membawa transformasi bagi kehidupan bangsa Israel dan berpengaruh pada kehidupan seluruh umat manusia sampai ke seluruh pelosok dunia. Yesus memberikan contoh dan gaya kepemimpinan yang patut dipanuti, diteladani bagi semua murid-murid-Nya dan tidak terkecuali bagi seluruh pemimpin-pemimpin rohani masa kini serta seluruh jemaat-Nya, dalam mengemban dan melaksanakan misi Kristus di dunia ini. Seorang pemimpin harus rela menyerahkan dirinya menjadi seorang hamba untuk melayani sesamanya, memberikan seluruh kehidupan dan pelayanannya untuk menjadi teladan dan terang bagi sesamanya, ia juga harus memiliki sikap loyalitas yang tinggi dan berdedikasi dalam membimbing, merangkul dan mengayomi jemaat-Nya untuk semakin bertumbuh dan dewasa di dalam Kristus Yesus.

Dalam kepemimpinan-Nya, Tuhan Yesus memberikan contoh dan teladan yang baik untuk dapat menjadi seorang pemimpin yang berkualitas dan dapat membawa perubahan yang besar ke arah yang lebih baik. Ia memberikan pola kepemimpinan-Nya yang membawa transformasi, yang teratur dan relevan bagi kepemimpinan rohani masa kini. Seorang pemimpin harus bersandar penuh dalam kedaulatan dan kuasa Allah Tritunggal untuk menjalankan dan mengembangkan kepemimpinan, agar 
sesuai dengan kehendak-Nya. Pemimpin harus mampu memilih, melengkapi dan menggerakkan orang dalam kuasa Roh Kudus untuk melayani. Ia juga harus mampu mendelegasikan tugas dan memotivasi dan memberikan visi bagi jemaat Tuhan untuk melaksanakan amanat Agung (Mat 28:18-20). Setelah semuanya selesai, seorang pemimpin yang baik juga harus mampu mengevaluasi hasil pelayanan dan kerjanya serta iman jemaat sejauh mana jemaat telah bertumbuh dan dewasa di dalam mengiring Yesus Kristus.

Seorang pemimpin rohani harus mencontoh dan meneladani kehidupan dan keteladanan Tuhan semasa hidup dan pelayanan-Nya. Setiap pengajaran-pengajaran yang diberikan kepada setiap orang yang mendengar, haruslah dapat merubah hidup orang yang mendengarkan berita keselamatan itu dan menjadikan mereka ciptaan baru seperti yang Tuhan Yesus ajarkan. Dalam bidang organisasi gereja, haruslah terdapat pembaruan, terutama dalam sikap dan perilaku seorang pemimpin kepada bawahan. Tuhan Yesus adalah Allah dan Tuhan, rela untuk melayani sebagai seorang hamba agar dapat menyelamatkan seluruh umat manusia.

\section{Saran-Saran}

Untuk sampai pada tujuan penulisan ini sehingga iman, pandangan dan sikap hidup pembaca sesuai dengan terang Alkitab, maka penulisan memberikan beberapa saran yang dianggap penting:

Pertama,diharapkan kepada setiap pemimpin rohani; baik itu gembala sidang, majelis gereja, maupun pemimpin-pemimpin dalam organisasi yang ada dalam suatu gereja agar dapat memahami dengan benar gaya dan cara pengembangan kepemimpinan Yesus Kristus dan bagaimana merealisasikan pelayanan yang Yesus lakukan ke dalam pelayanan kepemimpinan rohani.

Kedua, diharapkan agar setiap pemimpin-pemimpin rohani untuk menambah pengetahuan yang telah dimiliki dengan pengetahuanpengetahuan yang lain baik itu mengenai kepemimpinan maupun mengenai hal-hal yang menyangkut tentang kepemimpinan sehingga dalam memimpin, seorang pemimpin rohani dapat terus mengembangkan kepemimpinannya kepada perubahan yang lebih baik lagi.

Ketiga, diharapkan agar setiap pemimpin rohani tidak melihat dan menjadikan tradisi sebagai suatu halangan dan hambatan untuk merubah paradigma organisasi yang dipimpinnya, melainkan menggunakan tradisi yang ada untuk membuat sebuah terobosan yang baru dan menghasilkan pemahaman yang baru pula. 


\section{DAFTAR PUSTAKA}

Alan E. Nelson, Spirituality and Leadership (Bandung: Kalam Hidup, 2007)

B.F. Drewes, Satu Injil Tiga Pekabar_ (Jakarta: BPK Gunung Mulia, 1982)

Charles J. Keating, Kepemimpinan: Teori dan Pengembangannya

(Yogyakarta: Kanisius, 1988)

Gottfried Osei-Mensah, Dicari Pemimpin Yang Menjadi Pelayan,(Jakarta: Yayasan Komunikasi Bina Kasih/OMF)

Herman Soekahar, Bagaimana Memotivasi Jemaat Melayani. (Malang: Gandum Mas, 1988)

J. Oswald Sander, Kepemimpinan Rohani (Bandung: Kalam Hidup, 1979)

J.I.Packer, Merril C. Tenney, William White Jr., Dunia Perjanjian Baru (Malang; Gandum Mas, 1933)

J.L.Ch.Abineno, Doa Menurut Kesaksian Perjanjian Baru(Jakarta: BPK Gunung Mulia,1992)

J.M. Price, Yesus Guru Agung. (Bandung: LBB, 1975)

James Kouzes dan Barry Posner, A Leaders Legacy, (Jakarta: PT Bhuana Ilmu Populer, 2007)

James Kouzes dan Barry Posner, The Leadership Learning (Yogyakarta: Pustaka Baca, 2008)

James Strong, The Exhaustive Concordance Of The Bible. (Iowa: World Bible Publishers, n.d), s.v. "servant"

James Strong, The Exhaustive Concordance Of The Bible (Iowa: World Bible Publishers, n.d), s.v. "called".

John H. Zenger dan Joseph Folkman, The Handbook for Leaders, (Jakarta: PT Bhuana Ilmu Populer, 2004)

John Stott, Satu Umat (Malang: Seminary Alkitab Asia Tenggara, 1990)

Kamus Besar Bahasa Indonesia s.v. "Evaluasi” 
Kamus Besar Bahasa Indonesia s.v. "Memilih"

Kamus Besar Bahasa Indonesia s.v. "pola”

Kamus Besar Bahasa Indonesia, s.v. "Delegasi”

Kamus Besar Bahasa Indonesia. s.v. "hamba"

Kamus Besar Bahasa Indonesia. s.v. "teladan"

Kartini Kartono, Pemimpin Dan Kepemimpinan (Jakarta: PT Raja Grafindo Persada, 2008)

Kartini Kartono, Pemimpin Dan Kepemimpinan (Jakarta: PT Raja Grafindo Persada, 2008)

Ken Blanchard dan Phil Hodges, Lead Like Jesus (Jakarta: Visimedia, 2006)

Myron Rush, Pemimpin Baru (Jakarta: YPI “Imanuel”, 1991)

Paul Enns, The Moody Handbook Of Theology ( Malang: Literatur SAAT, 2004)

Peter Salim, The Contempary English - Indonesian Dictionary (Jakarta: Modern English Press, 1985)

Pontas Pardede, Sebuah Bunga Rampai Pertumbuhan Gereja

(Yogyakarta:Yayasan Andi,1994)

Renald Kasali, Re-Code Your Change DNA, (Jakarta: PT Gramedia Pustaka Utama, 2007)

Robert. E. Coleman Rencana Agung Penginjilan (Bandung: Kalam Hidup, 1964)

Xavier Leon-Dofour, Ensiklopedia Perjanjian Baru(Yogyakarta: Kanisius, 1990), s.v. "synoptik" 